\title{
Factors Causing Work Related Stress in the Hospitality Sector: A study of Employees in Three Star Hotels in Dehradun Region
}

\author{
Effulgence \\ Vol. 16 No. 1 \\ January - June, 2018 \\ Rukmini Devi Institute of Advanced Studies \\ E-mail : effulgence@rdias.ac.in, Website : www.rdias.ac.in \\ http:/ / effulgence.rdias.ac.in/user/default.aspx \\ https://dx.doi.org/10.33601/effulgence.rdias/v16/i1/2018/39-50
}

\section{Ekta Rao ${ }^{1}$ \\ Dr. Alok Goel ${ }^{2}$}

\begin{abstract}
Hotels are an important component of the hospitality sector as every tourist wants a comfortable and secure stay. Customers rate a tourist destination according to the performance of the hotels. The workforce of a hotel plays an important role in satisfying a customer. But the workforce is highly stressed because of a number of factors pertaining to the hotel industry. This paper aims to identify the factors causing work related stress among hotel employees. Descriptive research method was used to identify the factors causing stress and technique of factor analysis is applied. Findings of the study identified work load, control over work, role clarity, interpersonal relations, managerial support and organizational policies as six major factors causing stress among employees in the hotel industry. The findings of the paper are a guideline for the hotels to bring about modifications in these factors and hence improve mental well-being of their workforce.
\end{abstract}

Keywords: Hospitality, hotels, work related stress, service delivery

\section{INTRODUCTION}

$\mathrm{O}$ ver the past decade, a major feature of the hotel industry has been the rise of global players and the intensifying competition. This has caught hotels in a strategic bind: trying to minimize costs through applying a range of cost-cutting strategies and, at the same time, attempt to improve the quality service by implementing customer orientation programmes, etc (Cholli et al, 2017) There has also been a growing trend to subcontract out services and administrative functions, such as valet, cleaning, laundry, payroll and benefits processes, compliance and systems maintenance (Fox, 1998)Thus it is evident that a dichotomous nature of the hotel industry (i.e. fluctuating financial profits and tight margins versus the pressure to deliver quality services) is emerging.

The complex and ever changing environment of the hotel industry generates an ever ending array of stimuli, pressure and demands which become

1. Assistant Professor, Himalayan School of Management Studies, Swami Rama Himalayan University, Dehradun, erao1975@gmail.com

2. Visiting Scholar, Hasselt University, Belgium and STO, CSIR Human Resource Development Centre, Ghaziabad, alokgoel2006@gmail.com

Corresponding Author

Ekta Rao, Assistant Professor, Himalayan School of Management Studies, Swami Rama Himalayan University, Dehradun, erao1975@gmail.com 
sources of stress for hotel employees. (Hsin-Hui 'Sunny' Hu \& Chien-Wei Cheng, 2010). As a human based industry, hospitality depends on humans as part of the product, in which, cannot be separated from the service process (Ghazali, 2010). Employees having frequent face-to-face or voice-to-voice interactions with customers play a pivotal role in delivering service and establishing strong relationships with customers. Therefore, it is important to retain a pool of motivated, satisfied and committed employees for delivery of service quality and effective resolutions of customer complaints (Bowen \& Ford, 2004; Karatpe et al, 2009)

Moreover employees are always under public scrutiny as customers are dependent on them for their basic needs. Customers share their feedback through various websites which is again a challenge for the hotel industry. Customers are very demanding and want value for their money.

It is because of all these reasons that hotel employees are exposed to a high risk of work related stress. Work related stress results in employees becoming exhausted and cynical (Ross, 1994) and leads to reduction in their performance levels (Kim, 2009) and ultimately leading to negative effects on service delivery. Research has shown a negative correlation between job stress and quality customer service delivery (Varca, 1999, Beehr et al, 2000).

High stress levels have serious physical and psychological consequences for a hotel employee. Stress is manifested in the form of physiological symptoms, including headaches, fatigue, indigestion, ulcers, blood pressure, heart attacks, and strokes (Krone, Tabacchi, \& Farber, 1989) and psychological symptoms like declines in the quality of employee job performance (Gilboa, Fried, \& Cooper, 2008; Lepine, Podakoff, \& Lepine, 2005), decreases in employee ability to learn (Lepine, Lepine, \& Jackson, 2004), depression, hostility and withdrawal (Hemingway and Smith, 1999) Moreover WRS also leads to negative consequences for the organization as high stress levels among hotel employees lead to high absenteeism, low morale, poor motivation, high turnover rates and increased customer complaints.(Gole \& Sahu, 2008) All these factors negatively impact service delivery and reduce customer satisfaction which is a very crucial factor for the hotels in today's competitive scenario.

Hence it is imperative to focus on finding out the stressors in the hotel industry so that effective strategies can be framed manage them and improve well being of the work force and ultimately improve customer satisfaction.

\section{LITERATURE REVIEW: CAUSES OF WORK RELATED STRESS}

Work within the hospitality industry and for that matter, hotel, is highly labour intensive and has increasingly harsh environmental demands imposed upon it. The nature of work within hotels, according to Kristensen et al (2002) include hard deadlines, unexpected interactions with guests, long working hours, night and evening work, repetitive work, high emotional demands, low influence (control), shift work, high work space and problems with coordination of work. In their work, Lo and Lamm (2005) reported that working in the hospitality industry can be stressful and that many workers are vulnerable in terms of their poor working conditions and low wages.

Researchers have identified several factors which lead to occupational stress among employees of hospitality industry. Wallace (2003) identified fatigue as a result of working long hours, unpredictable shifts, few breaks, heavy physical demands (manual handling heavy loads, etc), and mental and emotional demands as stressors in the hospitality industry.

Low pay is also a concern since work is remunerated on the basis of qualification standards which tend to be set lower in relation to other service industries like nursing and policing (Haynes \& Fryer, 1999). Stressors have also been categorized as Employment 
factors (e.g. wages and conditions, employment relationships, company policies, etc.) as well as the roles played by the different interests groups (employers, trade unions and government agents). (Smith 2003)

Cartwright and Cooper (1997) identified six environmental sources as follows:

1. Factors intrinsic to the job itself

2. Roles in the organisation

3. Relationships at work (with supervisors, colleagues, and subordinates)

4. Career development issues

5. Organisational factors (e.g. organisational structure and climate)

6. The home-work interface.

Michie (2002) stressed that factors that are intrinsic to the job (long hours, work overload, time pressure, difficult or complex tasks, lack of breaks, lack of variety and poor working conditions); under work or conflicting roles and boundaries; under promotion, lack of promotion, lack of training and job insecurity are sources of stress at the work place. Ivancevich and Matteson (1980) suggest four clusters of work stressors: physical environment; individual level (a mixture of role and career development variables); group level (primarily relationship based); and organization level (a mixture of climate, structure, job design, and task characteristics).

The above discussion has revealed many work related stressors and in accordance with the objectives of the study the relevant stressors are identified and discussed below

\section{Work place demands}

Various studies have proven that individuals working in the hospitality industry show signs of stress and overwork, due to demands placed by organizations that tend to pressurize the employees.

Karatpe (2009) stressed that people working in tourism industry were under pressure because of private working conditions, long working hours, working weekends and holidays which bring in many problems and decrease moral and the level of enthusiasm of employees. Sheel. A (2014) stated that repeating the same job every day without any variety in the work activities also creates "worn-out" workers.

Hospitality workers are required to perform various unrelated tasks in a very limited time frame and without adequate training which is also a source of stress for them. (Johnson \& Woods, 2008)

The hotel environment exposes employees to unpredictable shift work, unrealistic deadlines which taxes their physical and emotional demands. (Lee and Wang, 2002) and hence leads to WRS among Hotel Employees.

The workplace demands are not only physical but have an emotional connotation also. According to Greenburg (2005) employees working in the hotel sector face emotional exhaustion while dealing with diverse clients. Employees have to smile all the time for hours and perform monotonous activities like greeting the customers, taking their orders and fulfilling their demands.

Demands at work include exposure to issues such as workload, work patterns and work environments; for example, volume and complexity of work, shift work, unrealistic deadlines (HSE, 2001). The hotel environment has been described as being characterized by working long hours, unpredictable shifts, few breaks and mental and emotional demands (Wallace, 2003). These contribute to the demand at work and hence result in WRS, especially when the employee perceives these demands as higher than his/her ability to cope with them.

\section{Control}

Control over work has also been identified as a major stressor for the hotel employees by many studies. Zohar (1994) conducted a survey of 
employees and managers in four Canadian hotels concluded that lack of control as an isolated factor is not a very strong predictor of stress but A work situation characterized by high ambiguity and low decision latitude, implying a lack of control over demands combined with a lack of authority to make decisions, was seen as a strong predictor of work stress.

The experience of pressure is strongly linked to perceptions of control. Lack of influence and consultation in the way in which work is organized and performed can be a potential source of WRS Examples of control at work are: lack of involvement in decision making, account not taken of staff ideas/suggestions about the job, lack of influence over performance targets and lack of time.

\section{Role}

Role conflict and role ambiguity are the two main dimensions of role stress which hotel employees faced with. (Babakus et al 2008; Kim et al, 2009).

Role conflict occurs when an individual receives incompatible job demands from his or her role partners, such as customers, co-workers, and managers, and is incapable of satisfying all the demands simultaneously (Churchill, Ford, \& Walker, 1976). Role ambiguity occurs when an individual lacks information about his or her job and experiences a great deal of uncertainty about how to perform job-related tasks (Churchill et al., 1976). Such role stressors lead to emotional exhaustion (Babakus et al., 2008).

Role has been identified as one of the major causes of WRS by other researchers also. Jamal (1990) and Cartwright et al (1995) have all identified role ambiguity as a stressor for hotel employees.

Dewettinck \& Buyens (2005) found that when there was no proper written procedure, employees often felt reluctant to react to various customers' complaints and this would eventually make the employees feel uncertain of how to interact with their customers. It is this uncertainty which leads to role related stress.

\section{Interpersonal Relations}

Hotel Employees have to face conflicting demands of company, customers and supervisors. These conflicts between employees and supervisors, employees and customers may give rise to stress for employees (Ruyter,2001). Padmakumar et al (2011) study highlights the fact that Interpersonal conflict is of utmost importance in hotel industry. Hotel employees have to respond promptly to the request of customers because of the real time nature of service delivery. Moreover the customer requests have to be fulfilled through coordination with other departments (Hales and Nightingale, 1986) It is this coordination which leads to interpersonal conflicts. Employees often face conflicting demands from guests and housekeeping management or may have to deal with embarrassing situations in the rooms. These have the potential of heightening WRS.

Paul (2002) has also identified that interpersonal relationship at workplace such as conflict with the policies of management, conflict with the supervisor's behavior, conflict with subordinates and conflict with the colleagues is a major stressor for hotel employees.

0'Neil and Davis (2011) conducted a study on hotel managers and hourly employees at 65 different hotels and identified interpersonal tensions are a major source of stress for hotel managers as well as hourly employees.

Catering for nightlife customers is also a major stressor for hotel employees. Parts of the hotel and catering industry are operating in the 'nighteconomy,' i.e., after dark. They are therefore centered on alcohol consumption and often targeted at young clients. These features potentially expose them to violence and related intimidation (Hobbs et al., 2002). 
Leather et al (1998) also suggests that physical violence is a problem in the sector. In particular, violence or the threat of violence seems to be quite a common experience of those who work in the 'nighteconomy.

As noted by Miller and Madsen (2003,) many frontline hospitality employees "feel their work is insulting, demeaning, and humiliating, as they cater to the needs and sometimes eccentric wants of customers." The phenomenon of "jaycustomer" behavior, which refers to customers who deliberately act in a thoughtless or abusive manner, can cause problems for the employees (Harris and Reynolds 2004).

\section{Income}

According to Haynes and Fryer (1999) low pay is a concern as far as WRS in the hotel industry is concerned. This, according to him, is because work in the industry is remunerated on the basis of qualification standards which tend to be set lower in relation to other service industries.

Aydın Civilidag. (2014) has also identified low salary levels as a source of stress among hotel employees in Turkey. Bula and Nyangahu (2015) in their study conducted in Nairobi have also concluded that low salary levels in the hospitality sector are a major stressor for all hospitality employees. He mentions that employees in the unorganized hospitality sector have very low salary levels as compared to the organized sector.

Furthermore, Arabi et al. 2013 is also in consonance with the view that hotel industry provide relatively low salary when compare to other sectors in Malaysia. An average salary of RM5, 686 per month is received by Malaysian who works in food, hospitality, tourism, and catering sector. On the contrary, a Malaysian who works in telecommunication sector receives, an average salary of RM11, 156. Apart from that, his research also found that higher average salary can be earned by shifting jobs to other sectors instead of staying in hotel industry.

\section{Support}

Lack of support from supervisors and co-workers has also been considered a stressor for employees of the hotel industry. It becomes a more noxious when combined with high demand and low control. (Maes, Van der Doef 1999). Pathak D (2012) studied the relationship between organizational support and work related stress and concluded that support from managers and coworkers helps in reducing stress levels of employees.

Organizational support refers to employees' general beliefs regarding the extent to which "the organization values their contributions and cares about their wellbeing" ( E. G. Mahon et al,2014). Support from superiors and coworkers can increase employees' inner obligation to help the organization reach its objectives and their affective commitment to the organization. Therefore, organisational support can increase employees' in-role and extrarole performance and decrease their stress and withdrawal behaviors. (Bobbio et al, 2015)

\section{Study Area}

Dehradun is the capital of the Indian state of Uttarakhand, near the Himalayan foothills. At its core is the 6-sided Ghanta Ghar clock tower. To the southwest is Paltan Bazaar, a busy shopping area. Just east is the Sikh temple Gurdwara Nanaksar, topped with ornate white and golden domes. In Clement Town to the city's southwest, Mindrolling Monastery is a Tibetan Buddhist center with shrine rooms in its Great Stupa.

Dehradun is a very famous tourist destination and the hospitality sector plays an important role in taking care of the tourists. Revenue from the hospitality sector is an important component of the state income 


\section{RESEARCH OBJECTIVE}

- To find out potential sources of stress in the hospitality sector employees in Dehradun.

- To identify which factors are major contributors towards work related stress in the hospitality sector.

\section{RESEARCH METHODOLOGY}

A descriptive research design is used for the study because the basic purpose is to provide description of the factors causing stress and no attempt is made to change the behavior. It is a cross sectional study conducted over a period of 11 months from June 2016 to July 2017.Twenty five '3 Star' hotels of Dehradun were chosen as the sampling frame. A sample size of 150 middle level management employees was taken for the study. An average of 6 employees were taken from each hotel. Questionnaire was administered on these hotel employees by personal visits to the hotels. Analytical tools like 'MS-Excel' and 'IBM-SPSS' was used to analyse the collected data.

\section{Research instrument}

'The Health and Safety Management Indicator' tool was modified with reference to the hospitality employees. Few changes were made in the questions with reference to the current study.

\section{Data Collection:}

The data has been collected from primary sources. Non-Probability sampling technique such as convenience sampling, judgmental sampling is used targeting a sample of 150 respondents.

\section{Reliability Test}

The consistency of the questionnaire can be evaluated by conducting reliability test which should be more than 0.6. The result of Cronbach's alpha was 0.921 which is a good measure of reliability.

Table 1: Reliability Measurement of the Scale

\begin{tabular}{|c|c|}
\hline Cronbach's Alpha & N of Items \\
\hline 0.921 & 29 \\
\hline
\end{tabular}

To identify the factors responsible for stress in employees working in the hospitality sector, factor analysis was applied. Kaiser-Meyer Olkin Measure of Sampling Adequacy (KMO) should be greater than 0.7 and the result of $\mathrm{KMO}$ is 0.895 . It means that the data is sufficient /adequate for factor analysis. Bartlett's test should always be less than 0.05 and the significance of the particular test drawn on the questionnaire is 0.000 .

Table 2: KMO and Bartlett's Test

\begin{tabular}{|c|c|c|}
\hline \multirow{2}{*}{ Kaiser-Meyer-Olkin } & Sampling Adequacy. & 0.895 \\
\hline \multirow{3}{*}{ Bartlett's Test of Sphericity } & Approx. Chi-Square & 1628.652 \\
\cline { 2 - 3 } & Df & 351 \\
\cline { 2 - 3 } & Sig & 0.000 \\
\hline
\end{tabular}

As per the Table 3 the total variance is explained from factors which results $69 \%$. Only those factors were chosen who Eigen values are more than 1 . Basing upon the factors loading given by rotated component matrix, six factors were identified. All the statements having cross-loadings were either removed or were associated with the factor having more relevance with the statement. 
The six factors identified are work load, control over work, role clarity, interpersonal relations, managerial support and organizational policies.
Overall the six factors account for $69 \%$ of the total variance explained. But variances of individual factors help in better understanding of factors causing stress. These are mentioned in the table.

Table 3: Results of Factor Analysis

\begin{tabular}{|c|c|c|c|c|c|}
\hline $\mathrm{F}^{*}$ & Variables in the factor & Eigen values & Factor loading & $\begin{array}{l}\text { Cronbach } \\
\text { Alpha }\end{array}$ & Total variance \\
\hline \multirow{6}{*}{ I } & $\begin{array}{l}\text { I am able to complete all tasks assigned within my } \\
\text { working hours. }\end{array}$ & \multirow{6}{*}{5.6} & 0.821 & \multirow{6}{*}{0.914} & \multirow{6}{*}{16.7} \\
\hline & $\begin{array}{l}\text { I feel that the work assigned to me requires me to work } \\
\text { very hard }\end{array}$ & & 0.763 & & \\
\hline & I have to perform a number of unrelated tasks & & 0.685 & & \\
\hline & $\begin{array}{l}\text { I have to work extra time in order to accomplish my } \\
\text { tasks }\end{array}$ & & 0.680 & & \\
\hline & $\begin{array}{l}\text { I feel that I work under a great deal of pressure I often } \\
\text { receive warnings for not completing my job in time. }\end{array}$ & & 0.647 & & \\
\hline & $\begin{array}{l}\text { I often receive warnings for not completing my job in } \\
\text { time. }\end{array}$ & & 0.562 & & \\
\hline \multirow{5}{*}{ II } & I can decide when to take a break & \multirow{5}{*}{4.3} & 0.794 & \multirow{5}{*}{0.869} & \multirow{5}{*}{8.7} \\
\hline & I have a say in my own work speed & & 0.766 & & \\
\hline & I have a choice in deciding what I do at work? & & 0.739 & & \\
\hline & I have a choice in deciding how I do my work? & & 0.645 & & \\
\hline & My working time can be flexible & & 0.638 & & \\
\hline \multirow{5}{*}{ III } & I am clear what is expected of me at work & \multirow{5}{*}{3.9} & 0.629 & \multirow{5}{*}{0.819} & \multirow{5}{*}{9.5} \\
\hline & I know how to go about getting my job done & & 0.717 & & \\
\hline & I know how to go about getting my job done & & 0.589 & & \\
\hline & I am clear what my duties and responsibilities are & & 0.588 & & \\
\hline & $\begin{array}{l}\text { I understand how my work fits into the overall aims of } \\
\text { the organization }\end{array}$ & & 0.504 & & \\
\hline \multirow{5}{*}{ IV } & $\begin{array}{l}\text { I normally encounter interpersonal differences and } \\
\text { disputes }\end{array}$ & \multirow{5}{*}{2.1} & 0.562 & \multirow{5}{*}{.811} & \multirow{5}{*}{11.3} \\
\hline & I am subject to bullying at work & & 0.697 & & \\
\hline & I have strained relationship with my supervisor & & 0.481 & & \\
\hline & I have strained relationship with my co-worker & & 0.617 & & \\
\hline & $\begin{array}{l}\text { I face problems in dealing with irate and demanding } \\
\text { guests }\end{array}$ & & 0.480 & & \\
\hline \multirow{5}{*}{$\mathrm{V}$} & I am given supportive feedback on the work I do & \multirow{5}{*}{2} & 0.685 & \multirow{5}{*}{.743} & \multirow{5}{*}{7.4} \\
\hline & $\begin{array}{l}\text { I can rely on my line manager to help me out with a } \\
\text { work problem }\end{array}$ & & 0.680 & & \\
\hline & $\begin{array}{l}\text { I can talk to my line manager about something that has } \\
\text { upset or annoyed me about work }\end{array}$ & & 0.647 & & \\
\hline & I am supported through emotionally demanding work & & 0.605 & & \\
\hline & My line manager encourages me at work & & 0.568 & & \\
\hline \multirow[t]{6}{*}{ VI } & $\begin{array}{l}\text { I am satisfied with the salary I am getting as compared } \\
\text { to my friends in other sectors }\end{array}$ & \multirow{6}{*}{1.19} & 0.629 & \multirow{6}{*}{.811} & \multirow{6}{*}{15.5} \\
\hline & $\begin{array}{l}\text { I am getting adequate and timely feedback about my } \\
\text { performance }\end{array}$ & & 0.721 & & \\
\hline & $\begin{array}{l}\text { I am provided adequate training for my current and } \\
\text { new assignments. }\end{array}$ & & 0.534 & & \\
\hline & $\begin{array}{l}\text { I get enough leaves to spend time with friends and } \\
\text { family. }\end{array}$ & & 0.578 & & \\
\hline & $\begin{array}{l}\text { Cancellation of holidays is a regular feature of the } \\
\text { organization* }\end{array}$ & & 0.504 & & \\
\hline & I have to work even on holidays. ${ }^{*}$ & & 0.502 & & \\
\hline
\end{tabular}


The first factor "Work load" explains $16.7 \%$ variance. It comprises of six statements which are mentioned in the table, along with the reliability of the scale. The second factor "Control over work" explains $8.7 \%$ of the variance and it comprises of five statements related to autonomy over the work which a hotel employee has. The third factor "Role clarity" explains $9.5 \%$ variation in the stress level of the employee and it comprises of five statements which intend to find whether the employee is clear about what is expected from him at work. The fourth factor "Interpersonal Relations" accounts for 11.3\% of the variance and comprises of five statements related to relationship with superiors, subordinates and customers. The fifth factor "Managerial Support" explain $7.4 \%$ of the variance and comprises of five statements. The sixth factor explains $15.5 \%$ of variance and comprises of six statements related to policies for compensation, holiday's etc. The reliability scale for each of the factors is mentioned in the table.

\section{FINDINGS OF THE STUDY}

Work load, Control over work, Role clarity, Interpersonal relations, Managerial Support, Organizational Policies have been identified as factors leading to Work Related Stress in the hospitality sector.

The first factor, workload, has been identified as the major contributor towards WRS among hotel employees. The findings of the current study are in consonance with the studies of Kristensen et al. (2000) and O' Neil and Davis (2011) who have also identified excessive work load as a major reason for causing stress in hotel employees. Further, hospitality workers are required to perform various unrelated tasks in a very limited time frame and without adequate training which is also a source of stress for them. (Johnson \& Woods, 2008)

According to HSE (2001), control over work includes: how much say and involvement the person has in the way they do their work. Although lack of control as an isolated factor is not a stressor, it becomes a stressor when combined with high demands at work. Control over work emerges as a unique feature in hotels which is characterized by the need to co-ordinate efforts between different departments and employees in a short timeframe, while at the same time having low levels of control over these other service providers (Zohar 1994) In other words, stress arises from being in charge without being in control. The same findings are reflected in the current study which reinforces our findings.

The third factor in the current study Role ambiguity is also a contributor towards WRS in the hotels. Employees in the hotels face a situation which is complex and unclear and this leads to emotional exhaustion and hence stress. These findings find assertion in the studies of Shani and Pazmi (2009) who also argued that role ambiguity is a factor causing stress in hotel employee.

In a hotel, the main task of employees is to communicate and deal with the customers and coworkers on daily basis. Various jobs have to be performed in coordination with other departments which often leads to interpersonal conflicts (Khurana et al,2012). Front office, room service, food and beverage, housekeeping departments have to work in an integrated manner to provide quality service to the customer. This often leads to interpersonal conflicts among employees who belong to different departments. These studies further reinforce the fourth factor of the current study i.e interpersonal relationships.

Hotel industry is a people intensive and requires emotionally demanding work. Support from superiors becomes a crucial factor to reduce stress level of employees. This leads us to the fifth factor Managerial support. Moreover when combined with high demands and low control, lack of managerial support becomes a more noxious factor. (Maes, Van der Doef 1999). 
Organizational policies related to salary and leave is the sixth factor identified in the current study. Low salary combined with less number of holidays and inability to maintain work life balance is also a factor leading to stress among employees in the hotel industry. Low salary especially in the unorganized hospitality sector is a major concern not only in India but countries all across the world. The findings of the current study are further asserted in the studies of Aydın Civilidag (2014) in Turkey, Nuanghu \& Bula (2015) Nairobi and Arabi et al, 2013 in Malaysia.

\section{CONCLUSION}

The hotel industry is viewing the impact of stress from a return on investment (ROI) and value on investment (VOI) perspective. Hotel industry is a labour intensive industry where investment in human resources are quite high. But high stress levels are reducing the productivity of the work force and hence the return on investment. (CGP \& SHRM, 2016).

The study is contributing to the hotel industry through identification of critical issues like work load, interpersonal relations and organizational policies which are leading to high stress levels among hotel employees. Identification of the stressors will be the first step in trying to reduce them.

\section{RECOMMENDATIONS}

Based on the findings of the study hotel industry can take some steps to improve the well-being of their employees.

- Human resource strategies in the hospitality sector should be designed in a way that an employee is able to maintain work life balance.

- Financial wellness programs can be implemented by hospitality employers with a large population of financially stressed workers to provide employees with personalized advice and customized financial education. Supporting employees in a way that addresses their daily concerns empowers financially stressed employees to gain a better perspective of their finances now and in the future.

- Stress audits should be conducted on a continuous basis to check stress levels of employees. Hotels should promote an environment where staff members are educated about the cause and symptoms of stress and help them to cope with the stress.

- Workshops on Emotional Intelligence can be conducted for hotel employees so that they develop the skills to manage their emotions and also understand the emotions of customers.

- Hotels should encourage open communication with staff members to identify individual stress profiles and how best to cope with these. They can hold one on one or small group discussions on stress related subjects.

- Job rotation and internal motivation opportunities should be provided to keep the staff members engaged and stimulated in their roles.

\section{LIMITATIONS AND FURTHER RESEARCH SCOPE:}

The study is limited to work related factors causing stress. It can also be extended to personal factors like personality, locus of control which affect stress levels. Demographic attributes have also not been considered in the study. The study is limited to Dehradun region and can be extended to other cities and states also.

\section{REFERENCES}

1) Aarabi, M. S., Subramaniam, I. D., \& Abu, Baker, Akeel, A. B. A. (2013). Relationship between Motivational Factors and Job Performance of Employees in Malaysian Service Industry. Asian Social Science. 9(9), 301-310.

2) Aydın, Civilidag. (2014).Hotel Employees' Mobbing, Burnout, Job Satisfaction And Perceived Organizational Support: A Research On Hospitality In Turkey. European Scientific 
Journal Vol.10, No.35,1-22

3) Babakus, E., Yavas, U. and Karatepe, O. M. (2008). The effects of job demands, job resources and intrinsic motivation on emotional exhaustion and turnover intentions: A study in the Turkish hotel industry. International Journal of Hospitality and Tourism Administration, 9(4): 384-404.

4) Beehr, T.A., Jex, S.M., Stacy, B.A., Murray, M.A.(2000).Work stressors and coworker support as predictors of individual strain and job performance. Journal of Organisation Behaviour, 21,391-405.

5) Bowen, C., \& Ford, R. C. (2004). What experts say about managing hospitality service delivery systems. International Journal of Contemporary Hospitality Management, 16(7), 394-401.

6) Cartwright, S., Cooper, C. L., \& Murphy, L. R. (1995). Diagnosing a healthy organization: A proactive approach to stress in the workplace. In L. R. Murphy, J. J. Hurrell Jr, S. L. Sauter \& G. Kieta (Eds.), Job stress interventions (pp. 217233). Washington, DC: American Psychological Association.

7) Cholli,C., Sreeraj ,P.S \& Pandey, S.(2017) To Study the Factors of Absenteeism in Hospitality Sector in India International Journal Of Multidisciplinary Research Vol-3, Issue-2, 2017 ISSN: 2454-1362

8) Churchill, G. A., Jr., Ford, N. M., \& Walker, O. C., Jr. (1976). Organizational climate community nurses. Journal of Nursing Research 10: 253-260.

9) Dewettinck, K.,\& D, Buyens. (2005).Role stress among front line employees. In : L. B. Van, P. Gemmel, and D. R.Van, Services management: An integrated approach, Second Edition. San Francisco: Prentice Hall.

10) Fox, R. (1998) Tourism and hospitality. management 4, No. 2, 331-339

11) Ghazali. H. (2010). Employee intention to leave a job. (Published Ph.D. Thesis). University of Waikato New Zealand.

12) Gilboa, S., Shirom, A., Fried, Y., Cooper, C. (2008). A meta-analysis of work demand stressors and job performance: examining main and moderating effects. Personnel Psychology, $61(2), 227-272$.

13) Gole, S.V \& Sahu, R. (2008). Effect of job stress and job satisfaction on performance: An Empirical Study, 2(3), 237-246

14) Greenberg, J. (2005). "Managing behavior in organizations". 4th Edition. New Jersey: Prentice Hall.

15) Hales C, Nightingale $M$ (1986). What are units managers supposed to do? A contingent methodology for investigating managerial role requirements. International Journal of Hospitality Management, 5(1),3-11.

16) Haynes, P., \& Fryer, G. (1999). Changing patterns of HRM and employment relations in New Zealand: the large hotel industry. Asia Pacific Journal of Human Resources, 37(2), 33-43.

17) Health and Safety Executive (2001) Tackling WRS: a managers' guide to guide to tackling WRS. Sudbury

18) Hemingway, M., Smith, C. (1999) Organizational climate and occupational stressors as predictors of withdrawal behaviors and injuries. Journal of Occupational and Organizational Psychology 3, 285-299.

19) Hina, Rehman . (2008) Occupational Stress and a Functional Area Of An Organization. International Review of Business Research Papers, Vol( 4) 163-173

20) Hobbs, D., Hadfield, P., Lister, S., Winslow, S., and Hall, S. (2002): Bouncers: the art and economics of intimidation. Violence research Programme, ESRC Economic and Social Research Council

21) $\mathrm{Hu}$ Hsin-Hui, Sunny \& Cheng Chien-Wei.( 2010). Job stress, coping strategies, and burnout among hotel industry supervisors in Taiwan, The International Journal of Human Resource Management 21(8), 1337-1350.

22) Ivancevich, J.M., \& Matteson, M.T (1980) Stress and work: A managerial perspective. Glenview, IL: cottforesman.

23) Jamal, M. (1990) Relationship of job stress and type A behaviour to employees job satisfaction, organisational commitment, psychosomatic 
health problems and turnover motivation. Human Relations 43: 727-738.

24) Johnson, M., \& R, Woods. (2008). Recognizing the emotional element in service excellence. Cornell Hotel and Restaurant Administration Quarterly, 49 (3), 310- 316.

25) Karatpe, O.M., \& Alesh Nloye, K.D. (2009). Emotional dissonance and emotional exhaustion among hotel employees in Nigeria. International Journal of Hospitality Management 28, 349-358.

26) Khurana. Ashok., Parida, Vinu., \& Shaveta, $T$ ,Grover . (2012) Identifying Reasons of Occupational Stress: A Study Of Women Employees International Journal of Multidisciplinary Management Studies,Vol.2 Issue 3, March 2012, ISSN 22498834

27) Kim, B.C. P., Murrmann, S. K., \& Lee, G. (2009). Moderating effects of gender and organizational level between role stress and job satisfaction among hotel employees. International Journal of Hospitality Management, 28(4), 612-619.

28) Kristensen T., Hannerz T., \& Tuchsen, F. (2002).Hospitalization among employees in Danish hotel and Restaurant Industry. European Journal of Public Health,12;192-197

29) Krone, C., Tabacchi, M., \& Farber, B. (1989). Manager Burnout. Cornell Hotel and Restau-rant Administration Quarterly 30 (3), 58-63

30) Lee,I.,\& Wang, H.H (2002) Perceived occupational stress and related factors in community nurses. Journal of Nursing Research 10: 253-260.

31) Lepine, J.A., Podsakoff, N.P., \& Lepine, M.A. (2005). A meta-analytic test of the challenge stressor-hindrance stressor framework: an explanation for inconsistent relationships among stressors and performance. Academy of Management Journal 48 (5), 764-775.

32) Lo, Karen, \& Lamm, Felicity. (2005). Occupational Stress in the Hospitality Industry an employment Relations Perspective. New Zealand Journal of Employment Relations 30(1) 23-47.

33) Michie, S. (2002) Causes and management of stress at work. Occupational Environment
Medicine 59: 67-72.

34) Miller, Douglas G. \& Susan R. Madsen. (2003).The development of an instrument to address the negative perception of Hospitality jobs: a pilot study. Journal of Human Resources in Hospitality and Tourism 2 (2): 75-92.

35) Nuanghu, K.P \& Bula, H,O(2015) Relationship between work stress and performance of employees: A case study of Transit Hotel in Nairobi City County, Archives' of Business Research Vol.3, No.6

36) O'Neill, J., \& W.D. Kelly. (2011). Work stress and well-being in the hotel industry. International Journal of Hospitality Management, (30), 38-47.

37) Padmakumar, R., Swapna, B., \& Gantasala, V. (2011). Work environment, service climate and customer satisfaction: Examining theoretical and empirical connections. International Journal of Business and Social Sciences, 2, 121-132

38) Pathak, D. (2012). Role of perceived organizational support on stress- satisfaction relationship: An empirical study. Asian Journal of Management Research, 3 (1), 153-177

39) Paul, E, S. (2002).Cross national differences in relationships of work demands, job satisfaction, and turnover intentions with work family conflict, Personnel Psychology. 60,805-835

40) Pulak,M .(2012), Beat that stress, Express Hospitality.pA-1.Retrieved from: http://hospitality.financialexpress.com/2012061 5/life01.shtml

41) R, Eisenberger., \& F, Stinglhamber. (2011) Perceived organizational support: fostering enthusiastic and productive employees, American Psychological Association, Washington, DC, USA, 2011. View at Publisher · View at Google Scholar

42) Ruyter, K., Wetzels, M., \& Feinberg, R. (2001).Role stress in call centers: Its effects on employee performance and satisfaction. Journal of Interactive Marketing. 15(2) 23-35

43) Shani Amir and Pizam Abraham (2009). WorkRelated Depression among Hotel Employees Cornell Hospitality Quarterly Online First, published on September 2, 2009 as 
doi:10.1177/1938965509344294

44) Sheel, A. (2014). Recent Trends in the Hospitality Industry. The Journal of Hospitality Financial Management, 12(1), 5-7.

45) Smith, P.A. (2003) Keynote Address: Monitoring the impact of shiftwork on employee well being. XVIth International Symposium on Night and Shiftwork, Santos, Brazil, November 18-21, 2003.

46) Varca, P.E., 1999. Work stress and customer service delivery. The Journal of Services Marketing 13 (3), 229-239.
47) Wallace, M. (2003). OSH implications of shiftwork and irregular hours of work: guidelines for managing shiftwork. Sydney: National Occupational Health and Safety Commission Development.

48) Workplace stress Impact and Outcome an India Study (2016). A collaborative study between Chestnut Global Partners and SHRM India.

49) Zohar, D. (1994). Analysis of job stress profile in the hotel industry. International Journal of Hospitality Management, 13, (3), 219-231. 